\title{
A JÖVEDELEMMINŐSÉG MÉRÉSE ÉS BEFOLYÁSOLÓ TÉNYEZŐI AZ EURÓPAI PÉNZÜGYI SZEKTORBAN
}

A szerzők tanulmányukban a jövedelemminőség mérésének lehetőségeit, valamint az arra ható tényezőket vizsgálják 128 európai bank 2006-2016 időszaki adatain. A jövedelemminőséget befolyásoló tényezők között a valós értékelés alkalmazásának mértéke, a szabályozottság foka és a banki méret hatásait elemezik, kitérve a válság előtti és válságidőszakban (2006-2011) és a válság utáni időszakban (2012-2016) tapasztalható különbségekre is. Vizsgálatuk eredményeképpen megállapítják, hogy a valós értéken értékelt vagyon aránya szignifikáns pozitív kapcsolatban van a jövedelem minőségével az európai tőzsdei bankok esetében, és ez a hatás a 2011-ben kihirdetett új valósérték-standardnak (IFRS 13) is köszönhetően tovább erősödött a válság utáni időszakban. További eredményeik alapján ugyanakkor arra a következtetésre jutnak, hogy az szigorúbb szabályozókörnyezet, valamint a bank méretének növekedése csökkentőleg hat a jövedelemminőségre.

Kulcsszavak: átlagos jövedelemminőség, valós értékelés, IFRS, válság

A vállalati teljesítmény egyik legfőbb indikátora a számviteli beszámolóban kimutatott nettó jövedelem (adózott eredmény), amely a vállalat külső és belső érintettjei számára kiemelt jelentőségü. Minél magasabb minőségű a kimutatott jövedelem - azaz minél hübben fejezi ki a vállalat valós jelenlegi és jövőbeli gazdasági teljesítményét, hozamtermelő képességét -, annál pontosabban mérhető a vállalatvezetés teljesítménye, a tulajdonosok által realizált megtérülés, továbbá annál kisebb kockázat mellett tudják meghozni a befektetők a vállalattal, illetve annak részvényeivel kapcsolatos döntéseiket. A jövedelem tehát a döntéshozatal egyik kulcstényezője (Schipper - Vincent, 2003). A jövedelemminőség kérdése nemcsak a kutatók, hanem a gyakorlati szakemberek és standardalkotók figyelmét is felkeltette az utóbbi egy-másfél évtizedben.

A szakirodalom széles körben foglalkozik a jövedelemminőség tartalmával. Általában véve a szerzők között egyetértés mutatkozik abban, hogy a jövedelem magas minősége legföképpen abban mutatkozik meg, hogy a vállalati teljesítményről pontos és megbízható képet ad, tehát informatív és a valós hozamtermelő képességet fejezi ki, ezáltal a döntéshozatal szempontjából hasznos (Dechow Schrand, 2004; Dechow és társai, 2010; An, 2017). Számos szerző szerint a jövedelem magas minősége azt is jelenti, hogy annak alakulása kiszámítható, tehát az adott időszaki jövedelem jó előrejelzője a későbbi időszakokénak (Penman, 2003; Hodge, 2003; Mikhail és társai, 2003), mások pedig a jövedelem részvényérték-becsléshez való felhasználhatóságát (Kirschenheiter - Melumad, 2004), illetve a müködési cash flow-val való együttmozgásának erősségét (Cohen, 2003) említik szempontként. Az e területen született legfrissebb kutatások már jellemzően e tényezők együtteseként, azaz több szempontot egyszerre érvényesítő kombinált mutatóként közelítik meg a jövedelemminőséget (lásd pl. Paoloni és társai, 2017).

A jövedelemminőség megfelelő definiálása azonban csak a mutató konzisztens mérésének lehetőségét teremti meg. A vállalati stakeholderek számára nyilvánvalóan az a fontosabb kérdés, hogy milyen tényezők és hogyan befolyásolják azt. A kapcsolódó publikációkat áttekintve megállapítható, hogy a jövedelemminőség egyik fő magyarázó változójaként a valós értékelés alkalmazása jelenik meg, ugyanakkor az eredmények vegyesek: Paoloni és társai (2017) arra a következtetésre jutnak, hogy a valós értékelés nagyobb arányú alkalmazása emeli a jövedelemminőséget, Sodan (2015) eredményei viszont negatív összefüggést tárnak fel a két változó között. A kutatók által vizsgált másik ilyen tényező a szabályozottság foka. Az ezzel foglalkozó tanulmányok (pl. Dichev és társai, 2013) konklúziója jellemzően az, hogy a magas minőségü standardok kedvezően hatnak a jövedelem minőségére. Arra a kérdésre azonban, hogy a szigorúbb vagy a megengedőbb szabályozási környezetben tapasztalható-e magasabb jövedelemminőség, kevéssé kapunk választ. Végül megemlítendő, hogy a befolyásoló tényezők között a publikált kutatások jelentős részében megjelenik a vállalati méret is. Ennek hatása kapcsán szintén nincs egyértelmü álláspont, egyes kutatók modelljeiben a méret emelkedésével együtt növekszik a kimutatott jövedelem minősége (pl. Gaio - Raposo, 2014), más tanulmányok szerint viszont csökken (pl. Cohen, 2003).

Tanulmányunkban a fent említett tényezőket koherens rendszerbe foglalva a valós értékelés, a szabályozottság foka és a vállalati méret jövedelemminőségre gyakorolt hatásait elemezzük az európai bankszektor 128 szereplöjének 20062016 közti adatait felhasználva. Mindeközben külön vizsgáljuk a 2000-es évek végén kialakult globális pénzügyi válság tágan vett időszakában (2006-2011) és az azt követő kilábalási időszakban (2012-2016) megfigyelhető különbségeket, a számviteli szabályzók fejlesztésének (mint a válságra adott válaszok) hatásait, valamint a tőzsdei és nem tőzsdei bankok eltéréseit. Irodalomkutatásunk során nem találtunk olyan tanulmányt, ami a vizsgált jelenséget ilyen kontextusban vizsgálja, így meggyőződésünk szerint az általunk alkalmazott megközelítéssel és empirikus eredményekkel hozzá tudunk járulni az aktuális hazai szakirodalomhoz.

\section{Irodalomkutatás}

Az irodalomkutatás során elsőként a jövedelemminőséggel kapcsolatos közelmúltbeli publikációkban megjele- 
nő fogalmi megközelítéseket tekintjük át, majd rátérünk a jövedelemminőség összetevőire, végül a valós értékelés és a jövedelemminőség különböző szerzők által feltárt viszonyát fejtjük ki röviden, specifikusan a pénzügyi szektorra koncentrálva.

An (2017) döntéshasznosság és elszámolhatóság szempontjából közelíti a jövedelemminőség (earnings quality, EQ) fogalmát: eszerint a jövedelem minősége akkor magas, ha a bevételi számok hasznosak a menedzseri, illetve befektetői döntéshozatal szempontjából. Dechow és Schrand (2004) szerint a magas jövedelemminőség azt jelenti, hogy az adott évi eredmény hüen tükrözi a cég jelenlegi müködési teljesítményét, illetve alkalmas a jövőbeli teljesítmény előrejelzésére és jó alapot szolgáltat a vállalat értékének meghatározásához, továbbá a jelenlegi részvényérték tükrözi annak belső értékét. Kirschenheiter és Melumad (2004) szerint magas minőségü az a jövedelem, amely informatív és közel van a cég hosszú távú vállalati értékéhez. További értelmezés szerint a jelenlegi jövedelem jó minőségü, ha a jövőbeli jövedelem megbízható magyarázó változójaként használható (Penman, 2003), vagy szoros kapcsolatban áll a jövőbeni müködési cash flow-val (Cohen, 2003). Schipper és Vincent (2003) a jövedelem minőségét hicksi jövedelemként definiálja, amivel a „valós” jövedelemmel való korrelációt lehet mérni. Yee (2006), valamint Mikhail és társai (2003) szerint a jövedelem minősége két elem, a fundamentális és a beszámolóbeli jövedelem viszonyától függ, tehát azon alapszik, hogy a beszámolóbeli jövedelem milyen gyorsan és pontosan tud reagálni a fundamentális jövedelem változásaira. Hodge (2003) a jövedelem minőségét úgy határozza meg, hogy az aktuális beszámolóbeli jövedelem mennyire esik közel a jövőbeli jövedelmekhez. Mikhail és társai (2003) ehhez hasonló definíciót adnak: álláspontjuk szerint a jövedelemminőség annak foka, hogy a vállalat korábbi jövedelme milyen mértékben képes hozzájárulni a jelenlegi jövedelméhez. Penman (2003) szerint a befektetők jövőbeli jövedelmet vásárolnak a részvények révén, az elemzők pedig a jövedelmek elörejelzése révén kívánják meghatározni a részvények értékét. Az értékelések központjában tehát a jövedelem található. Ily módon minél magasabb minőségü a jövedelem, annál pontosabb lesz a részvényekre vonatkozó értékmeghatározás. E gondolatot megerősítik Dechow és társai (2010), kiemelve, hogy a magasabb minőségü bevételek több információt nyújtanak a vállalat pénzügyi teljesítményének jellemzőiről, amelyek relevánsak egy adott döntéshozó által hozott konkrét döntéshez.

A fogalmi behatárolás mellett a nemzetközi szakirodalom jelentős figyelmet fordít a jövedelemminőséget befolyásoló tényezők beazonosítására. Francis és társai (2004) hét tényezőt azonosítottak be, melyek véleményük szerint együttesen megfelelően jellemzik az adott vállalkozás jövedelemminőségét. Ezek a tényezők a következők: az eredményelszámolás minősége (accounting quality, AQ), a jövedelem stabilitása (persistence, PERS), előrejelezhetősége (predictability, PRED), mesterséges simításának mértéke (earnings smoothing, SMOOTH), értékrelevanciája (value relevance, RELEV), időszerüsége (timeliness, TIMEL) és konzervativitásának mértéke (conservatism,
CONSER). Gaio (2010) a fenti tényezőket két csoportra osztja oly módon, hogy az első négy tényezőt (AQ, PERS, PRED és SMOOTH) alapvetően számvitel alapokon nyugvó tényezőknek, míg a RELEV, TIMEL és CONSER tényezőket piaci alapú mutatóknak tekinti.

Az egyik legfrissebb témába vágó kutatás Paoloni és társai (2017) írása, akik bankokat vizsgálva négy tényezőt alkalmaztak a jövedelemminőség meghatározására (melyek nagymértékben átfednek a Francis és társai (2004) által publikált tényezőkkel). Az átlagos jövedelemminőség (average earnings quality, AEQ) komponenseiként a jövedelem stabilitását vagy más szóval perzisztenciáját (persistence, PERS), előrejelezhetőségét (predictability, PRED), változékonyságát (variance, VAR) és mesterséges simítását (earnings smoothing, SMOOTH) azonosították. Koncepciójuk szerint a jövedelemperzisztencia (PERS) mutatója nem más, mint az

$$
X_{i, t}=\Phi_{0, i}+\Phi_{1, i} X_{i, t-1}+v_{i, t}
$$

autoregresszív modell $\Phi_{1, \mathrm{i}}$ paraméterének maximum likelihood módszerrel becsült értéke minden egyes bankra. (A modellben az $\mathrm{X}_{\mathrm{i}, \mathrm{t}}$ és $\mathrm{X}_{\mathrm{i}, \mathrm{t}-1}$ a tárgyévi és az előző évi adózott eredményt jelöli, míg a $\Phi_{0, \mathrm{i}}$ a tengelymetszetet, $\mathrm{v}_{\mathrm{i}, \mathrm{t}}$ pedig a véletlen tagot.) A perzisztencia tulajdonképpen az aktuális jövedelem jövőbeli fenntarthatóságának indikátora, ahol az 1-hez közeli értékek magasabb, a 0-hoz közeli értékek pedig alacsonyabb mértékű jövedelemstabilitást (ezáltal alacsonyabb jövedelemminőséget) jeleznek. Az említett autoregresszív modell véletlen tagjának $\left(\mathrm{v}_{\mathrm{i}, \mathrm{f}}\right)$ becsült szórásaként azonosítják a jövedelem előrejelezhetőségét (PRED), ahol az alacsony értékek jelentik a jobb elörejelezhetőséget, ami egyben jobb minőséget is takar. A jövedelmek változékonyságát egy újabb idősori jellemző, a jövedelem vizsgált perióduson belül tapasztalható szórása (VAR) hivatott mérni, értelemszerűen az alacsonyabb változékonyság magasabb minőségre utal. A mesterséges simítás (SMOOTH) a szerzők megfogalmazása szerint egy manipulatív (de legális, és a vállalatok által gyakran alkalmazott) technika, melynek célja a jövedelmek természetes szóródásának mesterséges csökkentése, hiszen a kevésbé szóródó jövedelmeket felmutató vállalatok részvényeit a befektetők biztosabb befektetésként értékelik, mint a magas volatilitásúakat. A SMOOTH mutatót a jövedelem szórásának és a müködési cash flow szórásának hányadosaként számítják. Ebböl következően a magas értékek arra utalnak, hogy a jövedelmek erősebben szóródnak, mint a cash flow értékek, azaz a vállalat kevésbé alkalmazza a mesterséges simítás technikáját. A magas SMOOTH értékek tehát kevésbé simított, azaz alacsonyabb minőségü jövedelmet fejeznek ki.

A szakirodalom egy másik - esetünkben releváns irányzatát a valós értékeléssel, valamint annak különböző teljesítmény- és piaci mutatókra gyakorolt hatásaival foglalkozó tanulmányok képezik. Ezen írások áttekintése jelen kutatás szempontjából azért fontos, mert közülük több tanulmány a valós értékelést a jövedelemminőség egyik magyarázó változójaként azonosítja.

A valós értékelést a Nemzetközi Pénzügyi Beszámolási Standardok (IFRS) rendszerében a 2000-es években az IAS 39 standard szabályozta, melyet a 2008-2009-es évek- 
ben kicsúcsosodott globális pénzügyi válság tanulságai alapján egy továbbfejlesztett, pontosított fogalommeghatározást tartalmazó új standard, a 2011-ben kibocsátott IFRS 13 váltott fel. E standardok célja mindenkor az volt, hogy a hagyományos bekerülési költségre alapozott értékmeghatározás helyett a számviteli beszámolókban minél nagyobb súlyt kapjon az eszközök és kötelezettségek értékelésekor az aktuális piaci viszonyokat hüen leképező valós érték, amely a beszámolók felhasználói számára nyilvánvalóan nagyobb mértékben tudja teljesíteni a megbízható és valós összképre vonatkozó elvárást, mint a költségalapú megközelítés. Hogy egy eszköz valós értékét milyen módon kell bemutatnia a gazdálkodó szervezetnek az információt igénylők számára, arra 2007-től az IFRS 7 standard ad megfelelö iránymutatást az ún. valósérték-hierarchia definiálásával. A valósérték-hierarchiában az értékmeghatározáskor figyelembe veendő inputadatoknak, információknak három (prioritási sorrendet kifejező) szintjét különbözteti meg a standard. A befektetői szempontból leginkább relevánsnak tekintendő 1. szintü információkat az értékelendő vagyonelemmel (legalábbis közel) teljes mértékben összehasonlítható, aktív piacokon jegyzett eszközök, illetve kötelezettségek piaci árai, árfolyamai jelentik. Az ilyen objektíven megfigyelhető inputokból, információkból közvetlenül meghatározható az értékelendő vagyonelem valós értéke. Amennyiben ilyen információk nem érhetők el, akkor 2. szintü inputok alapján kell megpróbálni meghatározni a valós értéket. Ebben az esetben nem aktív piacon jegyzett, csak kis volumenben megfigyelhető vagy kevésbé összehasonlítható inputadatokból indul ki az értékelö, melyeket megfelelö korrekciókkal lát el, hiszen az inputadat nyers formájában nem fejezi ki megfelelő megbízhatósági szint mellett az adott eszköz vagy kötelezettség reális értékét. A korrekciók alkalmazása természetesen szubjektív tartalmat visz az értékelésbe, mely által csökkenhet annak megbízhatósága. Végül, amennyiben sem az 1., sem a 2. szintü információk nem érhetők el, akkor a valós értékelést a 3. szintü információk alapján lehetséges csak megállapítani. Ez becslést jelent, ahol nem piaci információkból, hanem az értékelendő eszköz saját jellemzőiből, jövedelemtermelő képességéből kiindulva állapítja meg az értékelő a vagyonelem belső értékét, melyet valós értékként fogad el. Bár ezt a fajta értékelést a hierarchia legalsó szintjére helyezi a vonatkozó standard, jelentősége nem lebecslendő, hiszen gyakran (1-2. szintü inputok hiányában) ez jelenti az egyetlen járható utat.

A valós értékelés, illetve a valósérték-hierarchia alkalmazásának hatásait vizsgáló tanulmányok jelentős része a bankszektorra irányul (érthető módon, hiszen a valós értékelés által érintett pénzügyi eszközök, illetve kötelezettségek a pénzügyi intézmények vagyonában jelennek meg legerőteljesebben), és többségük a valós értékelés hasznosságát, alkalmazásának indokoltságát támasztja alá. Kolev (2008) egy amerikai pénzügyi vállalkozások adatait tartalmazó 172 elemü mintán vizsgálta a valós érték különböző modelljeit, és megállapította, hogy a befektetők lényegesen magasabb értéket tulajdonítanak az aktív piacok jegyzett áraiból származtatott (azaz 1. szintü inputokra alapozott) értéknek, mint a korrekciókon, illetve becslése- ken (azaz 2-3. szintü inputokon) alapuló értéknek. Bagna és társai (2014) 120 európai bank 2008-2012 közti adatait feldolgozva, OLS regressziós modell segítségével szintén a valósérték-hierarchia különböző szintjeinek árfolyamra vonatkozó relevanciáját elemezték. Empirikus eredményeik alapján - Kolev (2008) következtetéseit megerösítve kijelentik, hogy az 1. szintű inputokon nyugvó valós érték árfolyamra vonatkozó relevanciája szignifikánsan magasabb, mint a 2-3. szintű inputok esetében. Evans és társai (2014) összesen 7794 amerikai banki adatra támaszkodva a valós értéken meghatározott eszközérték és az árfolyam között mutattak ki pozitív együttmozgást, továbbá arra jutottak, hogy a valós eszközérték jobban magyarázza a jövőbeli árfolyamot, mint az azonos időszaki tőzsdei árat. Takács és Szücs (2017) megállapították, hogy bár a 20082009-es pénzügyi válság sok változást hozott a befektetői magatartásban, a banki részvények esetében a valós értékelésnek a befektetői döntésekre (részvényárfolyamokra) vonatkozó relevanciája a válság után is fennmaradt. Sun (2014) ugyanakkor ausztrál bankok adatait vizsgálva arra hívja fel a figyelmet, hogy a valós értékelés rendkívüli piaci volatilitást generálhat, így a megfelelő döntések meghozatala érdekében a befektetőknek meg kell érteniük a valós érték relevanciája és a volatilitás közti trade-off-ot.

Végül, kutatásunk szempontjából nagy jelentőségüek azok a tanulmányok, melyek kifejezetten a számviteli szabályozás, illetve azon belül konkrétan a valós értékelés és a jövedelemminőség összefüggéseit kutatják. Ewert és Wagenhofer (2005), Barth és társai (2008), továbbá Dichev és társai (2013) is a számviteli szabályzók hatásait vizsgálták a jövedelemminőségre, véleményük pedig egybecseng abban a tekintetben, hogy a magas minőségü számviteli standardok csökkentik a rosszhiszemü ,jövedelemmenedzsment" szerepét, ezáltal pedig növelik a számviteli beszámoló, azon belül is a kimutatott eredmény (jövedelem) minőségét. Ebből az is következik, hogy a standardok minőségének folyamatos javítása fontos és felelősségteljes feladat. Ezt egyebek mellett Barth (2000) tanulmánya támasztja alá, mely szerint a valós értékelés módjában, illetve annak következményeként a valós értékelésből származó nem realizált eredményben történő változások nemcsak a jelenlegi, hanem a jövőbeli vállalati teljesítményre is hatással vannak. A már hivatkozott Paoloni és társai (2017) a jövedelemminőség definiálásán, számítási módjának meghatározásán túl azt is vizsgálták banki adatokon, hogy a valós értékelés alkalmazása hatással van-e a jövedelemminőségre (modelljük magyarázó változóként a banki méretet és az eladósodottság fokát is tartalmazta). Eredményeik ezt a feltevést megerösítették, mely alapján állítják, hogy a valós értékelést alkalmazó bankok jövedelemminősége szignifikánsan magasabb. Kiemelik ugyanakkor, hogy a valós értékelés alkalmazása csak jól müködő piacokon tekinthető ésszerü döntésnek, a valós érték megbízhatósága, relevanciája és integritása együtt csökken a piac likviditásának és hatékonyságának csökkenésével, ami elötérbe hozza az egyéb értékelési technikákat, mellyel azonban csökken a jövedelem minősége. A valós értékelés hasznossága mellett állást foglaló tanulmányokon túl azonban - bár jelentősen kisebb számban - találhatók olyan kutatá- 
sok is, melyet a valós értékelés szemben foglalnak állást. Ezek közül említést érdemel Sodan (2015) munkája, amely szerint a valós értékelésből származó eredményhatások az egyéb átfogó eredmény révén negatív hatást gyakorolnak a vállalatok és a bankok aggregált jövedelemminőségére. Vizsgálata szerint a valós értékelésen nyugvó eszközarányos jövedelmezőség (ROA) mutatója kevésbé szignifikáns magyarázó változója a jövedelemminőségnek, mint a valós értékelés nélkül meghatározott ROA mutató.

Az elvégzett irodalomkutatás az alábbi tapasztalatokkal szolgált: először is kijelenthető, hogy a jövedelemminőség fogalmát a friss nemzetközi szakirodalomban alaposan kidolgozták. Másodszor, a valós értékelés jelentőségét, vállalati teljesítményre, illetve árfolyamra gyakorolt hatását számos tanulmány bizonyította. Harmadszor, korábbi tanulmányok kimutatták, hogy a valós értékelés a jövedelemminőséget is közvetlenül befolyásolja, hozzátéve, hogy a jövedelem minőségére egyéb magyarázó változók (pl. méret) is hatással vannak. Mindezekhez képest két ponton kívánjuk kiegészíteni a meglévő nemzetközi szakirodalmat. Egyrészt a hivatkozott tanulmányok nem foglalkoztak a számviteli szabályozók 2008-2009-es globális pénzügyi válság után bekövetkezett fejlesztésének, szigorodásának hatásaival, másrészt nem elemezték e hatások esetleges eltéréseit tözsdei, illetve nem tözsdei vállalatok/bankok esetében. Tanulmányunk e kutatási résekre koncentrál, és a fent említett kérdések megválaszolásával, valamint új empirikus eredményekkel járul hozzá a meglévő szakirodalomhoz.

\section{Kutatási koncepció, módszertan és adatok}

Tanulmányunkban az átlagos jövedelemminőségre ható tényezőket vizsgáljuk az európai bankszektorban, 128 európai bank 2006-2016 időszaki adatait felhasználva. $\mathrm{Az}$ átlagos jövedelemminőség (average earnings quality, AEQ) meghatározásakor Paoloni és társai (2017) irodalomkutatás során már részletesen kifejtett módszerét veszszük alapul. Eszerint az AEQ az 1. táblázatban bemutatott számviteli tényezők együtteseként adódik.

A fenti négy tényező közül a perzisztencia (PERS) esetében a magasabb, míg a többi három (PRED, VAR, SMOOTH) esetében az alacsonyabb értékek utalnak magasabb jövedelemminőségre (érthető módon, hiszen az alacsonyabb szórás a pénzügyi elemzésekben jellemzően a kisebb bizonytalanságot, nagyobb stabilitást jelzi, lásd például Katits és Patyi (2017) munkáját). A nyers értékek kiszámítása után a tényezők mindegyikénél egyszerü ranking módszert alkalmaztunk, ahol a mintabeli bankokat az adott tényező szerint rangsorba rendeztük oly módon, hogy a jövedelemminőség szempontjából legkedvezőbb értékkel rendelkező bank kapta a mintaelemszámnak megfelelő legmagasabb értéket (a teljes, 128 bankot tartalmazó mintában 128-at), míg a leggyengébb adattal rendelkező bank az 1-es értéket. Ezt követően adott bank átlagos jövedelemminőségét (AEQ) a négy tényezőből származó rangszámok egyszerű számtani átlagaként számítottuk ki.

Az AEQ alakulására ható tényezők (lehetséges magyarázó változók) közül a 2. táblázatban felsoroltakat építettük be a vizsgálatba.

\begin{tabular}{|l|l|l|}
\hline \multicolumn{1}{|c|}{$\begin{array}{c}\text { Független } \\
\text { változó }\end{array}$} & \multicolumn{1}{|c|}{ Jelölés } & \multicolumn{1}{c|}{ Kiszámítás módja } \\
\hline $\begin{array}{l}\text { Valós értékelés } \\
\text { alkalmazásának } \\
\text { mértéke }\end{array}$ & FVPBS & $\begin{array}{l}\text { a valós értéken } \\
\text { értékelt eszközök } \\
\text { átlagos aránya } \\
\text { a mérlegföösszeghez } \\
\text { képest a megfigyelt } \\
\text { időszakban }\end{array}$ \\
\hline Tözsdei jelenlét & EXCHANGE & $\begin{array}{l}\text { a tözsdén jegyzett } \\
\text { bankoknál 1, } \\
\text { egyébként } 0\end{array}$ \\
\hline $\begin{array}{l}\text { Európai ban- } \\
\text { kuniós tagság }\end{array}$ & EBU & $\begin{array}{l}\text { bankuniós } \\
\text { tagországbeli } \\
\text { bankoknál 1, } \\
\text { egyébként } 0\end{array}$ \\
\hline $\begin{array}{l}\text { A vagyon nagy- } \\
\text { sága (méret) }\end{array}$ & LGTA & $\begin{array}{l}\text { a megfigyelt időszak } \\
\text { átlagos } \\
\text { mérlegföösszegének } \\
\text { természetes } \\
\text { logaritmusa }\end{array}$ \\
\hline
\end{tabular}

2. táblázat Az átlagos jövedelemminőség ( $A E Q)$ lehetséges magyarázó változói

A valós értékelés alkalmazásának mértéke (FVPBS) a szakirodalomban feltárt számos tanulmány tanúsága szerint a jövedelemminőség egyik fő magyarázó változója lehet, így modellünkben is fontos szerepet kap. A tőzsdei jelenlét (EXCHANGE) és a 2012-től értelmezhető európai

\begin{tabular}{|c|c|c|}
\hline AEQ komponens megnevezése & Jelölése & Kiszámítása \\
\hline Jövedelemstabilitás, perzisztencia (persistence) & PERS & $\begin{array}{l}\text { az } X_{i t}=\Phi_{0, i}+\Phi_{1, i} X_{i, t-1}+v_{i, t} \text { autoregresszív modell } \\
\Phi_{1, \mathrm{i}} \text { paraméterének becsült értéke, ahol } X_{i, t} \text { és } X_{i, t-1} \text { a } \\
\text { tárgyévi, ill. előző évi adózott jövedelmet jelöli }\end{array}$ \\
\hline A jövedelem előrejelezhetősége (predictability) & PRED & $\begin{array}{l}\text { az } X_{i, t}=\Phi_{0, \mathrm{i}}+\Phi_{1, \mathrm{i}} X_{\mathrm{i}, \mathrm{t}-1}+\mathrm{v}_{\mathrm{i}, \mathrm{t}} \text { autoregresszív modell } \\
\text { véletlen tagjának becsült szórása: } \\
\text { PRED }=\sigma\left(\mathrm{v}_{\mathrm{i}, \mathrm{t}}\right)\end{array}$ \\
\hline A jövedelem változékonysága (variance) & VAR & $\begin{array}{l}\text { a jövedelem }\left(X_{i, t}\right) \text { vizsgált időszakon belüli szórása: } \\
\text { VAR }=\sigma\left(X_{i, t}\right)\end{array}$ \\
\hline Mesterséges simítás mértéke (earnings smoothing) & SMOOTH & $\begin{array}{l}\text { a jövedelem }\left(\mathrm{X}_{\mathrm{i}, t}\right) \text { szórásának és a múködési cash } \\
\text { flow }\left(\mathrm{CFO}_{\mathrm{i}, t}\right) \text { szórásának hányadosa: } \\
\mathrm{SMOOTH}=\sigma\left(\mathrm{X}_{\mathrm{i}, t}\right) / \sigma\left(\mathrm{CFO}_{\mathrm{i}, t}\right)\end{array}$ \\
\hline
\end{tabular}

1. táblázat $A z$ átlagos jövedelemminőség (AEQ) összetevői 
bankuniós tagság (EBU) figyelembevétele annak vizsgálatát szolgálja, hogy a tőzsdei cégeknél, illetve a bankuniós tagországoknál megjelenő relatíve szigorúbb és magasabb szintű szabályozottság hatással van-e a jövedelem minőségére. A vagyon nagyságának (LGTA) - ami a bank méretének jelzője - független változóként való alkalmazása pedig azon a hipotézisen alapul, hogy a különböző méretü vállalatok számviteli rendszereinek hatékonysága, minősége eltér, ami befolyásolhatja a jövedelemminőséget.

Kutatási koncepciónkat a fentiek alapján az 1. ábra foglalja össze.

\section{1. ábra A kutatási koncepció összefoglalása}

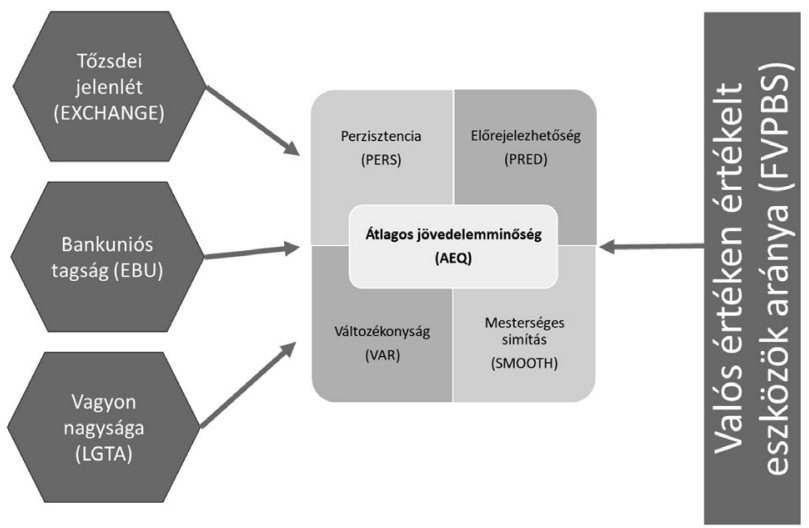

Amint korábban már említettük, az empirikus vizsgálat alapját egy saját gyüjtésü, 128 európai bank 2006-2016 időszaki beszámolóadatait tartalmazó minta képezte, melynek országonkénti összetételét a 3. táblázatban mutatjuk be.

\begin{tabular}{|l|r|r|}
\hline \multicolumn{1}{|c|}{ Ország } & $\begin{array}{r}\text { Bankok } \\
\text { száma } \\
\text { orszá- } \\
\text { gonként }\end{array}$ & $\begin{array}{c}\text { Bankok } \\
\text { száma } \\
\text { összesen }\end{array}$ \\
\hline Olaszország & 21 & 21 \\
\hline Németország & 13 & 13 \\
\hline $\begin{array}{l}\text { Franciaország, Oroszország, } \\
\text { Spanyolország, Törökország }\end{array}$ & 9 & 36 \\
\hline Nagy-Britannia & 7 & 7 \\
\hline Hollandia, Svájc & 6 & 12 \\
\hline Svédország & 5 & 5 \\
\hline Dánia, Görögország & 4 & 8 \\
\hline Ausztria, Belgium, Szlovénia & 3 & 9 \\
\hline $\begin{array}{l}\text { Finnország, Írország, } \\
\text { Magyarország, Norvégia, Portugália }\end{array}$ & 2 & 10 \\
\hline $\begin{array}{l}\text { Ciprus, Horvátország, } \\
\text { Lengyelország, Luxemburg, } \\
\text { Montenegró, Románia, Szlovákia }\end{array}$ & 1 & 7 \\
\hline Összesen: & $\mathbf{1 2 8}$ & $\mathbf{1 2 8}$ \\
\hline
\end{tabular}

3. táblázat Az adatbázisba került bankok megoszlása országonként
Minden bank minden vizsgált évére (azaz összesen 1408 bank-évre vonatkozóan) az IFRS szerinti beszámolóból kigyüjtöttük a mérleg, az eredménykimutatás és cash flow-kimutatás megfelelő adatait. Minden esetben a konszolidált beszámolók adataival dolgoztunk, melyek a hitelintézetek saját honlapjain voltak elérhetők. Valamennyi bank mérleg-, eredmény- és cash flow-adatait EUR-ban állapítottuk meg. Azon pénzintézeteknél, ahol a prezentálás pénzneme nem EUR volt, a beszámolóban kimutatott értékeket az Európai Központi Bank által közzétett árfolyamok ${ }^{1}$ alapján váltottunk át EUR-ra.

Az 1. ábrában kifejtett koncepciót elsőként az eredeti teljes mintán alkalmaztuk, melyből azután további módosított (banktípus, illetve időszak szerint szürt) mintákat hoztunk létre annak érdekében, hogy az összefüggéseket külön elemezhessük tőzsdei is nem tözsdei bankok esetében, valamint a globális pénzügyi válság előtti és a válságot magában foglaló időszak (2006-2011) és a válság utáni időszak (2012-2016) vonatkozásában. Megjegyezzük, hogy bár a válság kicsúcsosodása szigorúan véve csak a 2008-2009. évekhez köthető, a 2006-2011 időszak további bontását módszertani megfontolásokból nem tartjuk kivitelezhetőnek (a jövedelemminőség komponenseinek - például az autoregresszív modell paramétereinek - kéthárom éves idősorokból történő meghatározása nem szolgáltatna megbízható eredményt). Végeredményben így kilenc különböző adathalmazzal dolgoztunk, melyekre a későbbiekben a könnyebb beazonosíthatóság érdekében a 4. táblázat szerinti elnevezésekkel hivatkozunk.

\begin{tabular}{|l|r|l|c|c|}
\hline $\begin{array}{c}\text { A min- } \\
\text { tában } \\
\text { szereplö } \\
\text { bankok } \\
\text { típusa }\end{array}$ & $\begin{array}{c}\text { Minta- } \\
\text { elem- } \\
\text { szám (N) }\end{array}$ & $\begin{array}{c}\text { Teljes } \\
\text { időszak } \\
\mathbf{( 2 0 0 6 -} \\
\mathbf{2 0 1 6 )}\end{array}$ & $\begin{array}{c}\text { Válság } \\
\text { előtti és } \\
\text { válság- } \\
\text { időszak } \\
\mathbf{( 2 0 0 6 -} \\
\mathbf{2 0 1 1 )}\end{array}$ & $\begin{array}{c}\text { Válság } \\
\text { utáni } \\
\text { időszak } \\
\mathbf{( 2 0 1 2 -} \\
\mathbf{2 0 1 6 )}\end{array}$ \\
\hline $\begin{array}{l}\text { Összes } \\
\text { bank }\end{array}$ & 128 & 1. minta & la. minta & 1b. minta \\
\hline $\begin{array}{l}\text { Tőzsdei } \\
\text { bankok }\end{array}$ & 76 & 2. minta & 2a. minta & 2b. minta \\
\hline $\begin{array}{l}\text { Nem } \\
\text { tőzsdei } \\
\text { bankok }\end{array}$ & 52 & 3. minta & 3a. minta & 3b. minta \\
\hline
\end{tabular}

\section{4. táblázat A vizsgálat során elemzett minták}

Mint látható, a teljes, 128 elemủ mintából a típus szerinti szürés után a tőzsdei részmintába 76 , a nem tőzsdei részmintába pedig 52 bank került. Az időszak szerint szükített (a-val, illetve b-vel jelölt) minták esetében a megfigyelések száma $(\mathrm{N})$ már nem, csak a függő és független változók értékeinek meghatározásához felhasznált idősori adatok száma változott (a teljes minta 11 éves periódusához képest az $a$, illetve $b$ jelü szúkített mintákon 
rendre 6 , illetve 5 évnyi adat képezte a változóértékek alapját).

\section{Modellépítés}

Az előző fejezetben ismertetett koncepciónak megfelelöen az eredeti modellünk a következö:

$$
\begin{gathered}
A E Q_{i}=\alpha+\beta_{1} F_{V P B S}+\beta_{2} E X C H A N G E_{i}+ \\
\beta_{3} E B U_{i}+\beta_{4} L G T A_{i}+u_{i}
\end{gathered}
$$

Az (1) modellt a valamennyi (tőzsdei és nem tőzsdei) bankot tartalmazó és a teljes (2006-2016) időszakot lefedő 1. mintán teszteljük. Amikor a válság előtti és válságidőszakot (2006-2011), illetve a válság utáni időszakot (2012-2016) külön elemezzük, a fenti modellek némileg változnak. Ekkor ugyanis a jövedelemminőség, a méret és a valós értékeléssel kapcsolatos változók értékeit a szükített időszak idősorának értékeiből származtatjuk - ezt a változók neve elé írt ,,pre”, illetve ,post” előtaggal jelöljük -, míg az EXCHANGE változó e tekintetben nem függ az időszaktól, az EBU változó pedig (mivel a bankunió 2012től létezik) csak a 2012-2016 időszakban értelmezhető. Az így módosított modellek a következők:

$$
\begin{aligned}
\text { preAEQ }_{i}= & \alpha+\beta_{1} \text { pre FVPBS } \\
& +\beta_{2} E X C H A N G E_{i}+ \\
& \beta_{3} \text { pre } L G T A_{i}+u_{i}
\end{aligned}
$$

a 2006-2011 időszakra vonatkozóan, valamint

$$
\begin{gathered}
\text { post AEQ } Q_{i}=\alpha+\beta_{1} \text { post } F V P B S_{i}+\beta_{2} E X C H A N G E_{i}+ \\
\beta_{3} E B U_{i}+\beta_{4} \text { post } L G T A_{i}+u_{i}
\end{gathered}
$$

a 2012-2016 időszak esetében. Értelemszerüen a (2) modellt az 1a. mintán, míg a (3) modellt az 1b. mintán teszteljük. Amikor a tőzsdei és nem tőzsdei bankok, valamint azon belül a 2006-2011 és 2012-2016 időszakok jellemzőinek elkülönítése céljából a további (2. és 3., valamint 2a., 2b., illetve 3a., 3b.) részmintákat elemezzük, akkor az (1)-(3) modellekből az EXCHANGE magyarázó változót minden esetben elhagyjuk. Ennek oka, hogy akár tőzsdei, akár nem tőzsdei részmintáról van szó, e változó értéke minden megfigyelésnél azonos. A tesztelés során OLS regressziót futtatunk és az SPSS szoftvert használjuk fel.

\section{Eredmények és következtetések}

\section{Átfogó eredmények a teljes mintán}

Az empirikus vizsgálathoz elsőként az 1. mintát (128 tőzsdei és nem tőzsdei vállalat, 2006-2016 időszak) használtuk fel. A mintára vonatkozóan az (1) modell tesztelési eredményeit - ahol a releváns magyarázó változókat lépésenkénti (stepwise) regresszióelemzés segítségével azonosítottuk - az 5. táblázat foglalja össze.

Minta: 1. (tőzsdei és nem tőzsdei vállalatok, 20062016, $\mathrm{N}=128$ )

\section{Modelladatok:}

Modell: (1)

Függő változó: AEQ

$R$ négyzet: $46,8 \%$

\begin{tabular}{|llllll|}
\hline Magyarázó változók & Koefficiens & Std. hiba térték $p$ érték \\
\hline$\alpha$ (konstans) & 169,488 & 10,199 & 16,618 & $0,000^{* * *}$ \\
LGTA & $-23,333$ & 2,187 & $-10,669$ & $0,000^{* * *}$ \\
FVPBS & 35,473 & 10,503 & 3,377 & $0,001^{* * *}$ \\
\hline Kihagyott változók: & EXCHANGE, EBU &
\end{tabular}

Kihagyott változók: EXCHANGE, EBU

5. táblázat Az (1) modell teszteredményei az 1. mintán

Az eredmények alapján a teljes 2006-2016 időszak vonatkozásában arra következtethetünk, hogy a banki jövedelemminőségre (AEQ) két változó gyakorol szignifikáns hatást: a méret (LGTA) és a valós értékelés alkalmazásának mértéke (FVPBS), 46,8\%-os magyarázó erő mellett. A stepwise elemzés során a tőzsdei jelenlét (EXCHANGE) és a bankuniós tagság (EBU) nem került a modellbe, e két változó esetében tehát nem mutatható ki szignifikáns kapcsolat az AEQ-val. Az LGTA változó együtthatója negatív, tehát a banki méret növekedése a jövedelemminőségre csökkentőleg hat. Az FVPBS pozitív elöjele ugyanakkor alátámasztja a valós értékelés alkalmazásának kedvező hatását a jövedelem minőségére.

A vizsgálatot a következő lépésben az imént vizsgált

\begin{tabular}{|c|c|c|}
\hline \multicolumn{3}{|c|}{$\begin{array}{l}\text { Minta: 1a. (tőzsdei és nem tőzsdei vállalatok, 2006- } \\
\text { 2011, N=128) }\end{array}$} \\
\hline \multicolumn{3}{|c|}{$\begin{array}{l}\text { Modelladatok: } \\
\text { Modell: (2) } \\
\text { Függö változó: preAEQ } \\
\text { R négyzet: } 54,8 \%\end{array}$} \\
\hline \multicolumn{3}{|c|}{ Magyarázó változók Koefficiens Std. hiba térték pérték } \\
\hline $\begin{array}{l}\alpha \text { (konstans) } \\
\text { preLGTA } \\
\text { preFVPBS }\end{array}$ & $\begin{array}{r}170,980 \\
-23,232 \\
23,446\end{array}$ & $\begin{array}{ccc}8,671 & 19,719 & 0,000 * * * \\
1,889 & -12,298 & 0,000 * * * \\
8,815 & 2,660 & 0,009 * * *\end{array}$ \\
\hline \multicolumn{3}{|c|}{ Kihagyott változók: EXCHANGE } \\
\hline \multicolumn{3}{|c|}{$\begin{array}{l}\text { Minta: 1b. (tőzsdei és nem tőzsdei vállalatok, } 2012- \\
2016, \mathrm{~N}=128 \text { ) }\end{array}$} \\
\hline \multicolumn{3}{|c|}{$\begin{array}{l}\text { Modelladatok: } \\
\text { Modell: }(3) \\
\text { Függö változó: postAEQ } \\
\text { R négyzet: } 33,7 \%\end{array}$} \\
\hline \multicolumn{3}{|c|}{ Magyarázó változók Koefficiens Std. hiba térték p érték } \\
\hline $\begin{array}{l}\alpha \text { (konstans) } \\
\text { postLGTA } \\
\text { postFVPBS }\end{array}$ & $\begin{array}{r}150,799 \\
-19,088 \\
31,153\end{array}$ & $\begin{array}{rrr}11,420 & 13,205 & 0,000 * * * \\
2,360 & -8,087 & 0,000 * * * \\
10,304 & 3,024 & 0,003 * * *\end{array}$ \\
\hline
\end{tabular}
összefüggések válság előtti és válságidőszakra (20062011), valamint válság utáni időszakra (2012-2016) történő szétbontásával folytatjuk. Ennek érdekében elvégeztük a (2) és (3) modellek tesztelését is az la., illetve 1b. mintákon. A kapcsolódó eredményeket a 6. táblázat mutatja.

Kihagyott változók: EXCHANGE, EBU

6. táblázat $A$ (2) és (3) modellek eredményei az 1a.-1b. mintákon

A táblázatokban látható számok alapján a legfontosabb tanulság az, hogy a tőzsdei és nem tőzsdei bankokat együtt vizsgálva nincs számottevő eltérés a két részidő- 
szak (2006-2011 és 2012-2016) között. Mindkét vizsgált részperiódusban a méret és a valós értékelés bizonyult szignifikáns magyarázó változónak a jövedelemminőségre nézve. A méret mindkét esetben negatívan, a valós értékelés pedig pozitívan befolyásolta az AEQ mutatót. Megemlítendő azonban, hogy a modell magyarázó ereje a válság utáni időszakban alacsonyabb.

$\mathrm{Az}$ a tény, hogy a stepwise tesztelések során az EXCHANGE változó nem került a modellekbe, mindössze annyit jelent, hogy a tőzsdei jelenlét és a jövedelemminőség értéke között nem mutatható ki statisztikailag igazolható összefüggés. Abban azonban mutatkozhat eltérés, hogy a tőzsdei és nem tőzsdei bankok esetében, azon belül is a két időszak vonatkozásában mely tényezők mozgatják szignifikánsan az AEQ mutatót, és mekkora magyarázó erő kapcsolódik hozzájuk. Ezen esetleges eltérések kimutatása érdekében érdemesnek látjuk elvégezni az előzőhöz hasonló elemzést a tőzsdei és a nem tőzsdei részmintákon is, melyet a következö alfejezetben mutatunk be.

\section{A szabályozottság hatása}

Hipotézisünk szerint hatással van a bankok átlagos jövedelemminőségére az, hogy mennyire szigorúan szabályozott környezetben müködnek. Nem igényel bizonyítást, hogy a tőzsdei jelentések tartalmával, egyáltalán a tőzsdei vállalatok által negyedévente nyilvánosságra hozandó információkkal szemben erősebb elvárások fogalmazódnak meg, mint a nem tőzsdei cégek beszámolóival szemben. Az általunk vizsgált - a szabályozottság fokát jelző - másik jellemző a 2012-ben létrehozott bankunióban való tagság. Az Európai Parlament definíciója szerint ,a bankuniót a pénzügyi válságra reagálva hozták létre és jelenleg két eleme van, az egységes felügyeleti mechanizmus (SSM) és az egységes szanálási mechanizmus (SRM). Az egységes felügyeleti mechanizmus az euróövezet legnagyobb és legfontosabb bankjait ellenőrzi közvetlenül európai szinten, míg az egységes szanálási mechanizmus célja a csődbe jutó bankok rendezett körülmények között, az adófizetők és a reálgazdaság számára minimális költségekkel történő szanálása"².

Összességében tehát a szabályozottság fokát e két bináris változóval mérjük, ahol a tőzsdei jelenlét (EXCHANGE), illetve a bankuniós tagság (EBU) változók 1-es értéke a magasabb, a 0 érték pedig az alacsonyabb mértékü szabályozottságot fejezi ki. Reálisnak tűnő várakozás, hogy a szabályozottság fokának emelkedésével a jövedelemminőség emelkedik, továbbá előzetesen vélelmezhető, hogy ez az összefüggés eltérően jelentkezhetett a 2006-2011 és a 2012-2016 időszakokban. E hipotézis alátámasztása vagy megcáfolása céljából először áttekintettük az átlagos AEQ alakulását az egyes részmintákon, melyre a 7. táblázat szerinti eredményeket kaptuk. (A feltüntetett értékek az eredeti, 128 elemủ mintán számított, az adott típusba és adott időszakhoz tartozó előfordulások AEQ átlagait fejezik ki.)

\begin{tabular}{|c|c|c|}
\hline \multicolumn{3}{|c|}{$\begin{array}{l}\text { Átlagos jövedelemminőség (AEQ) tőzsdei és } \\
\text { nem tőzsdei bankoknál válság előtt és után }\end{array}$} \\
\hline Banktípus & $\begin{array}{l}\text { Válság előtti és } \\
\text { válságidőszak } \\
\text { (2006-2011) }\end{array}$ & $\begin{array}{l}\text { Válság utáni } \\
\text { idöszak } \\
\text { (2012-2016) }\end{array}$ \\
\hline $\begin{array}{l}\text { Tözsdei bankok } \\
\left(E X C H A N G E_{i}=1\right)\end{array}$ & 59,22 & 59,61 \\
\hline $\begin{array}{l}\text { Nem tőzsdei bankok } \\
\left(E X C H A N G E_{i}=0\right)\end{array}$ & 72,12 & 71,64 \\
\hline \multicolumn{3}{|c|}{$\begin{array}{l}\text { Átlagos jövedelemminőség (AEQ) EBU és nem EBU } \\
\text { tagországbeli bankoknál válság előtt és után }\end{array}$} \\
\hline Banktípus & $\begin{array}{l}\text { Válság előtti és } \\
\text { válságidőszak } \\
\text { (2006-2011) }\end{array}$ & $\begin{array}{l}\text { Válság utáni } \\
\text { időszak } \\
\text { (2012-2016) }\end{array}$ \\
\hline $\begin{array}{l}\text { EBU tagországbeli } \\
\text { bankok }\left(E B U_{i}=1\right)\end{array}$ & - & 61,84 \\
\hline $\begin{array}{l}\text { Nem EBU tagor- } \\
\text { szágbeli bankok } \\
\left(E B U_{i}=0\right)\end{array}$ & - & 68,79 \\
\hline
\end{tabular}

7. táblázat Átlagos AEQ értékek a banktípus és időszak szerinti részmintákon

Ezek az adatok az előzetes várakozással ellenkező következtetést alapoznak meg. A táblázatban bemutatott értékek ugyanis azt jelzik, hogy a nem tőzsdei és (2012-től) a nem EBU tagországbeli bankok esetében magasabb jövedelemminőség-adatokat tapasztalhatunk, mint a tőzsdei, illetve bankuniós országokhoz tartozó bankok esetében. Ez pedig egyértelmúen arra utal, hogy a szigorúbb szabályozási környezet nem magasabb, hanem alacsonyabb jövedelemminöséget eredményez. E felismerés mellett itt is fontos kérdés lehet a méret és a valós értékelés alkalmazásának AEQ-ra gyakorolt hatása, melyre vonatkozóan a (2) és (3) modellek tőzsdei és nem tőzsdei, valamint idöszak szerinti részmintákon kapott regressziós eredményeiből (melyek a 8-9. táblázatokban láthatók) vonhatunk le következtetéseket.

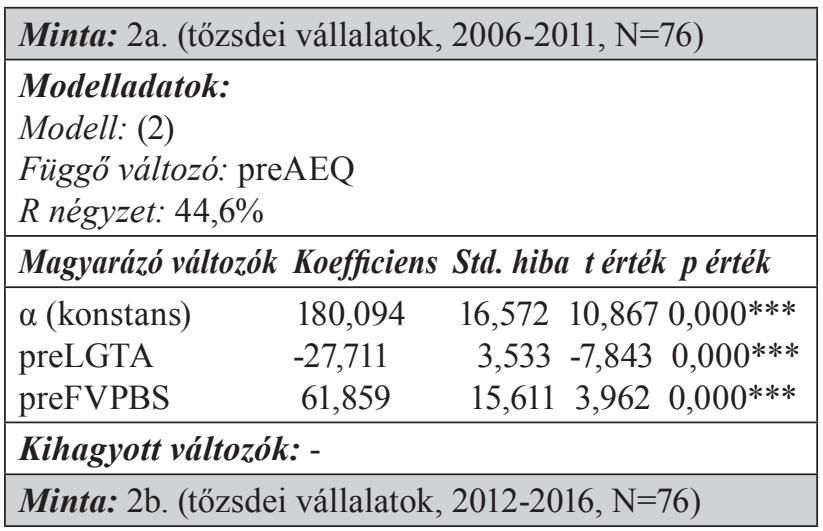




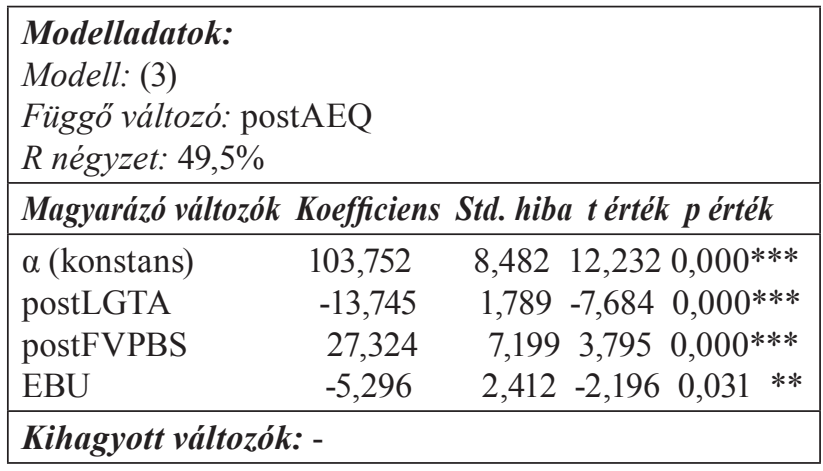

8. táblázat A (2) és (3) modellek teszteredményei a 2a.-2b. mintákon

Minta: 3a. (nem tőzsdei vállalatok, 2006-2011, N=52)

\section{Modelladatok:}

Modell: (2)

Függő változó: preAEQ

R négyzet: $16,9 \%$

Magyarázó változók Koefficiens Std. hiba térték p érték

$\begin{array}{lllll}\alpha \text { (konstans) } \quad 143,142 & 21,008 & 6,814 & 0,000^{* * *}\end{array}$

$\begin{array}{llllll}\text { preLGTA } & -15,116 & 4,488 & -3,368 & 0,001 * * *\end{array}$

Kihagyott változók: FVPBS

Minta: 3b. (nem tőzsdei vállalatok, 2012-2016, N=52)

Modelladatok:

Modell: (3)

Függő változó: postAEQ

$R$ négyzet: -

Magyarázó változók Koefficiens Std. hiba térték pérték

Kihagyott változók: postLGTA, postFVPBS, EBU

9. táblázat A (2) és (3) modellek teszteredményei a 3a.-3b. mintákon

A teszteredmények arról árulkodnak, hogy a korábban megállapított összefüggések elsősorban a szigorúbb szabályozással jellemezhető tőzsdei bankoknál figyelhetők meg. A méret emelkedésének jövedelemminőségre gyakorolt csökkentő hatása igazolást nyert a válság előtti és válság utáni tőzsdei mintán egyaránt, továbbá - bár gyenge magyarázó erővel - a válság előtti nem tőzsdei mintán (az LGTA változó együtthatója minden említett esetben negatív). A nem tőzsdei vállalatok esetében a válság utáni időszakban egyetlen független változó sem bizonyult szignifikánsnak, a jövedelemminőséget tehát ebben az esetben más tényezők befolyásolják. A tőzsdei vállalatoknál a 2012-2016 időszakban 5\%-os szinten az EBU változó is szignifikánssá vált, mégpedig negatív együtthatóval, ami igazolja a bankuniós tagság kedvezőtlen hatását a jövedelem minőségére, a válság előtti időszakhoz képest továbbá 44,6\%-ról 49,5\%-ra emelkedett a modell magyarázó ereje.

Mindemellett fontos következtetések vonhatók le a valós értékelés hatásával kapcsolatban. Az FVPBS változó abszolút szignifikáns és pozitív előjelủ a tőzsdei vállalatok mindkét időszaki részmintáján, ugyanakkor nem mutat összefüggést az AEQ változóval a nem tőzsdei mintán. Mindez pedig azt jelenti, hogy a valós értékelés nagyobb mértékü alkalmazása magasabb átlagos jövedelemminöséget eredményez, de ez a jelenség csak a tözsdei bankoknál figyelhetö meg. A stepwise elemzés ugyanakkor arra is rámutatott, hogy a válság utáni mintán nemcsak a modell teljes magyarázó ereje, hanem az FVPBS független változó $R$ négyzethez való hozzájárulása is magasabb, ami értelmezhető annak jeleként, hogy a számviteli standardalkotók válságra adott válasza sikeres volt, és a 2011-ben kihirdetett IFRS13 standarddal valóban sikerült növelni a valós értékelés hatékonyságát, ami a banki jövedelemminőségre gyakorolt pozitív hatás erősödésében érhető tetten.

\section{Összegzés}

Kutatásunk a jövedelemminőséget (AEQ) és a rá ható tényezőket a korábban publikált tanulmányokhoz képest új kontextusban vizsgálja, ahol a valós értékelés, a szabályozottság és a méret AEQ mutatóra gyakorolt hatásainak megfigyelése mellett külön figyelmet kap a válság elötti és válságidőszak (2006-2011) és az azt követő kilábalási időszak (2012-2016) különbségeinek, valamint a tőzsdei és nem tőzsdei bankok eltéréseinek vizsgálata.

A valós értékelés alkalmazása kapcsán eredményeink arra utalnak, hogy a valós értéken értékelt eszközök nagyobb aránya magasabb jövedelemminőséget indukál, ami megegyezik Paoloni és társai (2017) megállapításaival. Megjegyzendő azonban, hogy ezen összefüggést csak a tőzsdei bankoknál tudtuk igazolni, a nem tőzsdei bankok esetében nem találtunk kapcsolatot a két változó között. Jelentős felismerésnek tekintjük azt, hogy a valós értékelés jövedelemminőségre gyakorolt pozitív hatása a válság utáni kilábalási időszakban (2012-2016) a korábbi (2006-2011) időszakhoz képest felerősödött, ami a standardalkotás (az új IFRS 13 standard) sikerességének jeleként értelmezhető. Másként fogalmazva: ez az összefüggés igazolja, hogy a standardok minőségének emelkedése kedvezö hatással van a banki jövedelmek minőségére.

Ezzel szemben a tőzsdei jelenlét és a 2012-től létező bankuniós tagság vonatkozásában arra a következtetésre jutottunk, hogy a nem tőzsdei, illetve a nem bankuniós tagországbeli bankok átlagos jövedelemminősége magasabb, tehát önmagában a szabályozottság fokának emelkedése (a szabályozás szigorodása, a szolgáltatandó információk részletességének, mélységének kibővítése) nem emeli meg az AEQ értékét, sőt, csökkentőleg hat rá.

A banki méret hatását illetően - a szakirodalomban található vegyes megállapításokkal szemben - eredményeink egyértelmüen azt jelzik, hogy a vagyon nagyságának emelkedésével az átlagos jövedelemminőség csökken. Minden modellünkben a méret bizonyult a teljes R négyzethez legnagyobb mértékben hozzájáruló változónak, és minden esetben negatív együtthatóval. Ennek egyik magyarázata az lehet, hogy a mérettel együtt vélhetően a vállalat számviteli rendszerének bonyolultsága, komplexitása is növekszik, ami az AEQ mutatót befolyásoló komponenseket kedvezőtlen irányba mozdítja el.

Kutatásunknak természetesen vannak korlátai. Empirikus eredményeink az általunk kiválasztott 128 európai bank 2006-2016 időszaki adatain alapulnak. Más bankok 
ugyanezen időszaki adatainak, vagy ugyanezen bankok más időszaki adatainak felhasználásával az eredmények eltérhetnek. Következtetéseink relevanciája továbbá esetlegesen alacsonyabb lehet néhány hivatkozott, több ezer vállalat adatait tartalmazó nagymintás kutatás eredményeihez képest. Mindemellett úgy véljük, hogy az általunk vizsgált 1408 bank-év kellően nagy bázist ad ahhoz, hogy a kapott eredményeket megbízhatónak és gyakorlati implikációk szempontjából relevánsnak tekintsük. Meggyőződésünk, hogy az itt közölt empirikus eredmények mind az európai banki vezetők, mind a befektetők számára hasznos segítséget nyújthatnak döntéseik elökészítésében és meghozatalában.

\section{Felhasznált irodalom}

An, Y. (2017): Measuring Earnings Quality Over Time. International Journal of Economics and Financial Issues, 7(3), p. 82-87.

Bagna, E. - Di Martino, G. - Rossi, D. (2014): An Anatomy of the Level3 Fair Value Hierarchy Discount. No 65, DEM Working Papers Series from University of Pavia, Department of Economics and Management. p. 46., available at: https://papers.ssrn.com/sol3/papers. cfm?abstract_id $=2367405$

Barth, M. E. (2000): Valuation-based research implications for financial reporting and opportunities for future research. Accounting and Finance 40, p. 7-31. DOI: http://dx.doi.org/10.1111/1467-629X.00033

Barth, M. E. - Landsman, W. R. - Lang, M. H. (2008): International accounting standards and accounting quality. Journal of Accounting Research, 46(3), p. 467-498. DOI: http://dx.doi.org/10.1111/j.1475-679X.2008.00287.x

Cohen, D. A. (2003): Quality of Financial Reporting Choice: Determinants and Economic Consequences. Working Paper, Northwestern University. DOI: http://dx.doi.org/10.2139/ssrn.422581

Dechow, P. - Schrand, C. (2004): Earnings Quality. The Research Foundation of CFA Institute, p. 1-160.

Dechow, P. - Ge, W. - Schrand, C. (2010): Understanding earnings quality: A review of the proxies, their determinants and their consequences, Journal of Accounting and Economics, 50(2-3), p. 344-401.

Dichev, I. D. - Graham, J. R. - Harvey, C. R. - Rajagopal, $S$. (2013): Earnings quality: Evidence from the field. Journal of Accounting and Economics, 56(2), p. 1-33. DOI: http://dx.doi.org/10.1016/j.jacceco.2013.05.004

Evans, M. E. - Hodder, L. - Hopkins, P. (2014): The Predictive Ability of Fair Values for Future Financial Performance of Commercial Banks and the Relation of Predictive Ability to Banks' Share Prices. Contemporary Accounting Research, Vol. 31, Spring, p. 13-44. DOI: http://dx.doi.org/10.1111/1911-3846.12028

Ewert, R. - Wagenhofer, A. (2005): Economic effects of tightening accounting standards to restrict earnings management. The Accounting Review, (80), p. 1101-1124. DOI: http://dx.doi.org/10.2308/accr.2005.80.4.1101
Francis, J. - LaFond, R. - Olsson, P. - Schipper, K. (2004): EQ and the Pricing Effects of Earnings Patterns. Available at SSRN: https://papers.ssrn.com/sol3/ papers.cfm?abstract_id $=414142$

Gaio, C. (2010): The relative importance of firm and country characteristics for earnings quality around the world. European Accounting Review, (19), p. 693-738. DOI: http://dx.doi.org/10.1080/09638180903384643

Gaio, R. - Raposo, C. (2014): Corporate Governance and Earnings Quality: International Evidence. Journal of Accounting and Finance, 14(3), p. 52-74.

Hodge, F. (2003): Investors' Perceptions of Earnings Quality, Auditor Independence, and the Usefulness of Audited Financial Information. Accounting Horizons, (17), p. 37-48. DOI: http://dx.doi.org/10.2308/acch.2003.17.s-1.37

Katits, E. - Patyi, B. (2017): A nyugat-dunántúli régió öszszehasonlító elemzése a pénzügyi kockázati faktorok azonosításával. Gazdaság \& Társadalom, 9(2), p. 70-98.

Kirschenheiter,M.-Melumad,N.(2004):Earnings'qualityand smoothing. Working Paper, Columbia Business School. DOI: http://dx.doi.org/10.2139/ssrn.930445

Kolev, K. (2008): Do investors perceive marking-to-model as marking-as-myth? Early evidence from FAS 157 disclosure. Available at. https:/www.kellogg. northwestern.edu/accounting/papers/KalinKolev.pdf

Mikhail,M.-Walther, B.-Willis, R. (2003):ReactionstoDividend Changes Conditional on Earnings Quality. Journal of Accounting, Auditing and Finance, 18 (1), p. 121-151. DOI: http://dx.doi.org/10.1177/0148558X0301800107

Paoloni, M. - Paolucci, D. - Menicucci, E. (2017): Fair value accounting and earnings quality (EQ) in banking sector: Evidence from Europe. African Journal of Business Management, 11(20), p. 597-607.

Penman, S. (2003): The quality of financial statements: Perspectives from the recent stock market bubble. Accounting Horizons, (17), p. 77-96.

DOI: http://dx.doi.org/10.2308/acch.2003.17.s-1.77

Schipper, K. - Vincent, L. (2003): EQ. Accounting Horizons, 17 (Supplement), p. 97-111.

Sodan, S. (2015): The impact of fair value accounting on EQ in eastern European countries. Procedia Economics and Finance, (32), p. 1769-1786.

Sun, L. (2014): Fair Value and Its Economic Consequence on the Volatility Measures of Earnings, Stock Price and Government Debt Yield. Theoretical Economics Letters, (4), p. 910-915.

DOI: http://dx.doi.org/10.4236/tel.2014.49114

Takacs, A. - Szucs, T. (2017): How Fair Value Regained Its Importance after the Crisis: Empirical Evidence from the European Banking Sector. International Research Journal of Finance and Economics, (163), p. 7-16.

$Y e e, K$. (2006): Earnings quality and the equity risk premium: A benchmark model. Contemporary Accounting Research, (23), p. 833-877.

DOI: http://dx.doi.org/10.1506/8M44-W1DG-PLG4$8 \mathrm{E} 0 \mathrm{M}$. 